\title{
ARTICLE
}

\section{Relationship between zooplankton biomass and continental water discharges in the southern Gulf of Mexico (1984-2001)}

Relación entre la biomasa zooplanctónica y las descargas de aguas continentales, en el sur del Golfo de México (1984-2001)

\author{
Faustino Zavala-García ${ }^{1}$, Cesar Flores-Coto ${ }^{1}$ and \\ María de la Luz Espinosa-Fuentes ${ }^{1}$
}

\begin{abstract}
${ }^{1}$ Laboratorio de Zooplancton, Instituto de Ciencias del Mar y Limnología, Universidad Nacional Autónoma de México, A.P. 70-305, 04510 México, D.F. México. fauszavala@gmail.com

Resumen.- La biomasa zooplanctónica es reconocida como un importante indicador de la producción secundaria; su variación espacio-temporal en zonas neríticas es afectada particularmente por las descargas de los ríos, por lo que se analiza el efecto espacio temporal de las descargas de aguas continentales en la distribución de la biomasa zooplanctónica en el sur del Golfo de México, en 5 áreas frente a las costas de Veracruz, Tabasco y Campeche. El material analizado proviene de 534 muestras recolectadas en diferentes estaciones climáticas entre 1984 y 2001. Los volúmenes de descargas de 5 regiones hidrológicas se obtuvieron de la base de datos gubernamentales. Los resultados muestran que las variaciones de la biomasa durante las estaciones del año en las diferentes áreas son muy similares al patrón de las descargas. Los mayores valores de biomasa ocurren enfrente de las costas de Tabasco y los menores frente a Veracruz, donde se tienen las mayores y menores descargas de aguas continentales respectivamente. La variación de la biomasa depende de las descargas, no sólo en términos de un ciclo anual, sino también directamente relacionada con el tamaño del volumen vertido al océano. El análisis de árbol permitió concluir que en el sur del Golfo de México sobre la parte externa de la plataforma y zona oceánica, la biomasa siempre es baja, independiente de la estación del año o del área de que se trate. La mayor biomasa ocurre sobre la plataforma en profundidades bajas, pero su magnitud varía dependiendo del área y de la época. La biomasa frente a Campeche no depende de las descargas de aguas continentales sino se genera sobre la plataforma de Yucatán.
\end{abstract}

Palabras clave: Biomasa zooplancton, Golfo de México, agua de descargas continentales, técnica CART

\begin{abstract}
Zooplankton biomass is recognized as an important indicator of secondary production, its spatial and temporal variation in neritic zones is particularly affected by discharges of the rivers, and the spatial-temporal effect of continental water discharges on the distribution of zooplankton biomass in the southern Gulf of Mexico was analyzed for 5 areas off the coasts of Veracruz, Tabasco and Campeche. The analyzed material was obtained from 534 samples collected during different climatic seasons from 1984 to 2001. The discharge volumes of 5 hydrological regions were obtained from the government's data base. The results obtained indicated that biomass variation throughout the seasons in the different areas was very similar to the pattern of discharges. The greater biomass values were recorded off Tabasco and the lower values off Veracruz, where the greater and lower continental water discharges were recorded respectively. Biomass variation depended on the discharges, not only in terms of an annual cycle, but was also directly related to the volumes discharged into the ocean. A Tree analysis made it possible to conclude that biomass is always low on the outer shelf and oceanic region of the southern Gulf of Mexico, independently of the season of the year or of a particular area. A greater biomass was recorded on the shallow shelf, with a magnitude that varied in relation to the area and season. The biomass off Campeche did not depend on the continental water discharges, but was generated on the Yucatán shelf.
\end{abstract}

Key words: Zooplankton biomass, Gulf of Mexico, continental water discharges, CART technique

\section{INTRODUCTION}

Zooplankton biomass has been widely recognized as an important indicator of secondary production (Boltovskoy 1981, Clark et al. 2001), apart from being a key factor in moving energy from primary production to higher trophic levels in pelagic food chains (Kane 1993, Fernández de Puelles et al. 1996, Clark et al. 2001, Steinberg et al. 2008). Its variation in space and time thus determines the dynamics of the system. 
The patterns of distribution and abundance of zooplankton are affected by factors of a trophic nature (Reaugh et al. 2007, Steinberg et al. 2008), as well as hydrodynamic factors such as currents, gyres, mixing and stratification of the water column, distance from the coast (Salas de León et al. 1998, EspinosaFuentes et al. 2009) and continental water discharges (Grimes \& Finucane 1991).

Water circulation in the Gulf of Mexico is strongly influenced by the Loop Current (Nowlin 1972). Coastal currents in particular have a marked seasonal cycle, and move to the south from October to March over the Veracruz and Tabasco shelves to the point where they meet an opposite current that originates as a branch of the Yucatán current. The coastal currents then move to the north throughout the year (ZavalaHidalgo et al. 2003).

The coupling between the distribution of planktonic organisms and the hydrodynamics in the Bay de Campeche in the southern Gulf of Mexico has been analyzed for different climatic seasons by Flores-Coto et al. (1988, 1993), Salas de León et al. (1998) and Espinosa-Fuentes et al. (2009). These authors stated that the general distribution of zooplankton is strongly affected by river discharges and the meso-scale cyclonic gyre, and observed a marked gradient in zooplankton biomass from the coast offshore.

High densities of zooplankton biomass recorded in coastal areas (Flores-Coto et al. 1988, Gasca et al. 1994, Salas de León et al. 1998, Espinosa-Fuentes et al. 2009) indicate an association between zooplankton and high primary production systems, generated by continental water discharges and forming coastal fronts rich in nutrients, which in turn constitute areas that favour the feeding and growth of planktonic organisms (Biggs \& Sánchez 1997, Chen et al. 1997, Chen et al. 2002, Vera-Mendoza \& Salas de León 2014).

This emphasize the importance of coupling between physical and biological processes in production processes. Thus, the purpose of this study was to analyze the spatial-temporal effect of continental water discharges on the distribution of zooplankton biomass on the continental shelf and oceanic region of the southern Gulf of Mexico during different climatic seasons, based on data recorded over more than fifteen years (19842001).

\section{MATERIALS AND METHODS}

The study area is located in the southern Gulf of Mexico between $18^{\circ}$ and $21^{\circ} 30^{\prime} \mathrm{N}$ and $91^{\circ}$ and $97^{\circ} \mathrm{W}$, along the coasts of the states of Veracruz, Tabasco and Campeche (Fig. 1). The southern Gulf of Mexico is a highly dynamic coastal system that receives considerable volumes of water from the rivers and coastal lagoons of the states of Veracruz, Tabasco and Campeche, as well as from the Yucatán Canal currents. All this water carries great amounts of organic and inorganic materials and makes this one of the most important fishery areas of the country (Gracia et al. 1997). The main rivers that provide runoff to the Campeche Bay and Campeche Sound are the GrijalvaUsumacinta, Papaloapan, Coatzacoalcos, Tecolutla, Tuxpan, Antigua, Nautla, Candelaria and Cazones (Comisión Nacional del Agua 2009) ${ }^{1}$.

These continental water discharges are collected in 5 hydrological regions, 3 located in the state of Veracruz (Veracruz Norte, Papaloapan and Coatzacoalcos), one in Tabasco (Grijalva-Usumacinta) and one in Campeche (Yucatán Oeste). Of these, the one with the greatest catchment area is the Grijalva-Usumacinta with $102,465 \mathrm{~km}^{2}$, whereas the Yucatán Oeste has only $25,443 \mathrm{~km}^{2}$ (Comisión Nacional del Agua 2009) $)^{1}$.

Continental water discharges favour the formation of coastal fronts in neritic areas. The presence and the ecological role of coastal fronts in the study area have been recorded by several authors (Czitrom et al. 1986, Alatorre et al. 1989, MonrealGómez et al. 1992, Espinosa-Fuentes \& Flores-Coto 2004). Since organisms tend to gather near fronts, the distribution of waste and pollutants may be affected by their presence (Klemas 1980, Salas de León et al. 1998).

The study area is characterized by the presence of cold fronts, mainly from October to April (Tapánes \& González-Coya 1980). The presence of a cold front in the Gulf produces northerly winds, locally known as 'northers' that reach 30 $\mathrm{m} \mathrm{s}^{-1}$; these meteorological characteristics over the Gulf of Mexico affect the coastal zone through freshwater discharges, modify the position of the thermocline making it deeper, and generally affect circulation (Shirazago 1991).

Material was obtained from 534 samples collected in the southern Gulf of Mexico during 14 oceanographic cruises carried out on the R/V Justo Sierra during different seasons of the year from 1984 to 2001 (Table 1). Three cruises took place during winter, 4 in spring, 3 in summer and 4 in autumn.

Each of the 5 hydrological regions were considered as study area: areas 1- Norte de Veracruz, 2- Papaloapan and 3Coatzacoalcos, in the state of Veracruz, area 4 to the hydrological region Grijalva-Usumacinta in Tabasco and area 5 to the hydrological region Yucatán Oeste in Campeche (Fig. $1)$.

${ }^{1}$ Comisión Nacional del Agua. 2009. Atlas del Agua en México, México. <www.conagua.gob.mx> 


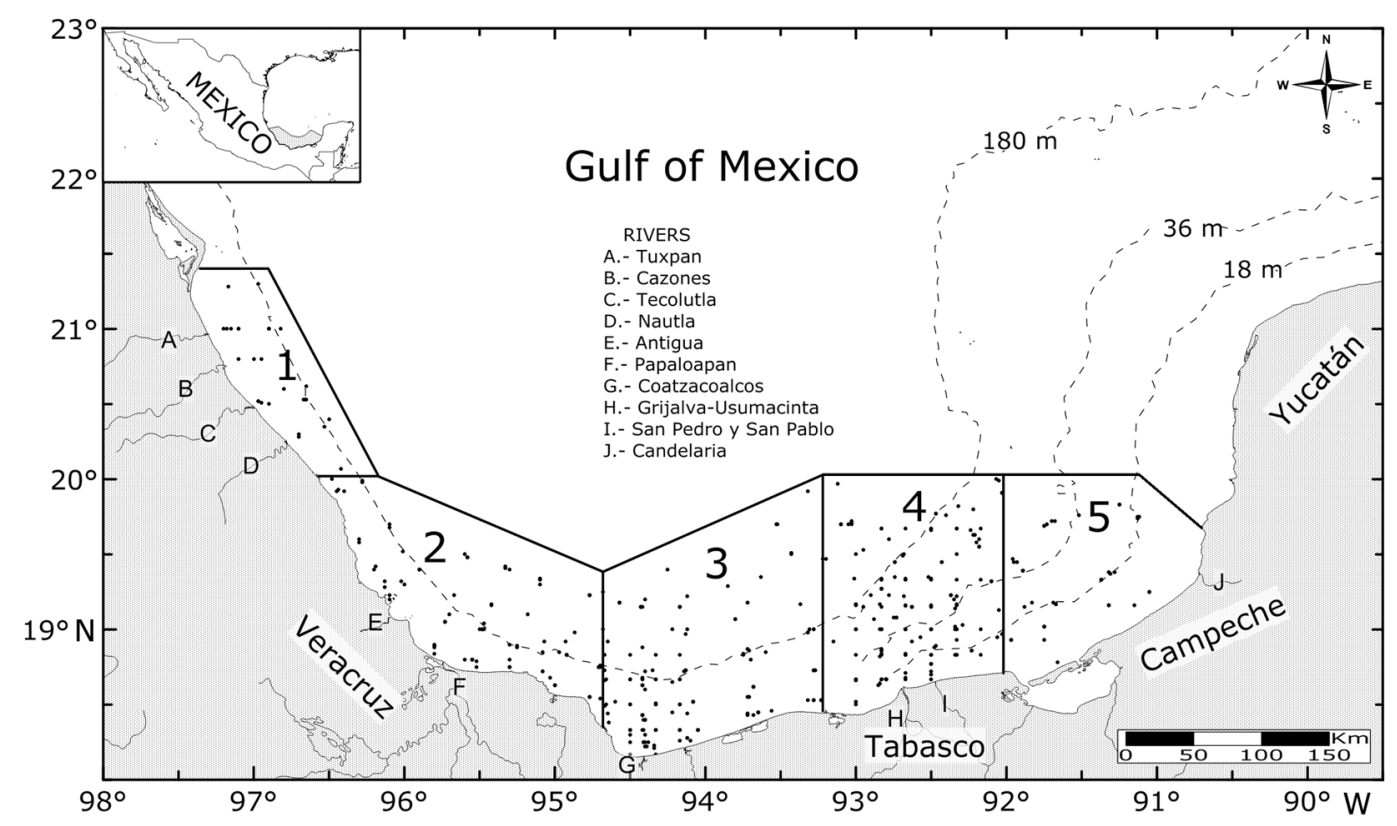

Figure 1. Study area, location of sampling stations and hydrological areas (1-5) / Área de estudio, ubicación de las estaciones de recolecta de zooplancton y áreas hidrológicas (1-5)

Table 1. Used oceanographic cruises for the analysis of zooplankton biomass. Year, season, number of samples and study area / Cruceros oceanográficos empleados para el análisis de la biomasa de zooplancton. Año, estaciones climáticas, número de muestras y área de estudio

\begin{tabular}{|c|c|c|c|c|c|}
\hline \multirow[b]{2}{*}{ Cruises } & \multirow[b]{2}{*}{ Year } & \multirow[b]{2}{*}{ Season } & \multirow[b]{2}{*}{ Samples } & \multicolumn{2}{|c|}{ Study area } \\
\hline & & & & $\begin{array}{l}\text { Latitude } \\
\text { min-max }\end{array}$ & $\begin{array}{l}\text { Longitude } \\
\text { min-max }\end{array}$ \\
\hline PROGMEX I & 1983 & Spring & 40 & 18.22 to $20.53^{\circ} \mathrm{N}$ & 91.13 to $96.95^{\circ} \mathrm{W}$ \\
\hline IMECO & 1984 & Winter & 20 & 18.25 to $21.00^{\circ} \mathrm{N}$ & 91.28 to $97.15^{\circ} \mathrm{W}$ \\
\hline PROGMEX II & 1984 & Spring & 30 & 18.22 to $20.53^{\circ} \mathrm{N}$ & 91.13 to $96.97^{\circ} \mathrm{W}$ \\
\hline PROGMEX III & 1984 & Summer & 46 & 18.22 to $20.53^{\circ} \mathrm{N}$ & 91.12 to $96.97^{\circ} \mathrm{W}$ \\
\hline OGMEX I & 1987 & Winter & 42 & 18.33 to $21.00^{\circ} \mathrm{N}$ & 91.05 to $96.90^{\circ} \mathrm{W}$ \\
\hline OGMEX II & 1987 & Summer & 58 & 18.25 to $21.00^{\circ} \mathrm{N}$ & 91.05 to $97.18^{\circ} \mathrm{W}$ \\
\hline OGMEX III & 1987 & Autumm & 42 & 18.25 to $19.91^{\circ} \mathrm{N}$ & 91.05 to $95.80^{\circ} \mathrm{W}$ \\
\hline OGMEX V & 1988 & Summer & 67 & 18.25 to $21.30^{\circ} \mathrm{N}$ & 91.32 to $97.17^{\circ} \mathrm{W}$ \\
\hline OGMEX VI & 1988 & Autumm & 26 & 18.30 to $21.00^{\circ} \mathrm{N}$ & 94.04 to $97.20^{\circ} \mathrm{W}$ \\
\hline OGMEX VII & 1989 & Winter & 42 & 18.25 to $19.50^{\circ} \mathrm{N}$ & 92.80 to $95.80^{\circ} \mathrm{W}$ \\
\hline PROMEBIO II & 1999 & Autumm & 34 & 18.23 to $19.34^{\circ} \mathrm{N}$ & 92.33 to $94.67^{\circ} \mathrm{W}$ \\
\hline PROMEBIO III & 2000 & Spring & 33 & 18.21 to $19.34^{\circ} \mathrm{N}$ & 92.33 to $94.67^{\circ} \mathrm{W}$ \\
\hline PROMEBIO IV & 2001 & Spring & 20 & 18.50 to $19.67^{\circ} \mathrm{N}$ & 92.33 to $93.01^{\circ} \mathrm{W}$ \\
\hline PROMEBIO V & 2001 & Autumm & 34 & 18.17 to $19.67^{\circ} \mathrm{N}$ & 92.17 to $94.67^{\circ} \mathrm{W}$ \\
\hline
\end{tabular}


The information in the data base of the Banco Nacional de Datos de Aguas Superficiales BANDAS (IMTA 2000), recorded for 27 hydrometric stations over a period of 50 years, was consulted in order to obtain the volume of the average monthly discharges of the 5 hydrological regions.

A Bongo net with mesh sizes of 333 and $505 \mu$ m was used to collect the zooplanktonic material. Trawling was double oblique for 5 to $20 \mathrm{~min}$ at maximum depth of $200 \mathrm{~m}$, as bathymetry allowed. The volume of filtered water was calculated using flowmeters (General Oceanics, model 2030R) placed at the mouth of the net.

The zooplankton samples were preserved in $4 \%$ formalin, neutralized with sodium borate and later transferred to $70 \%$ alcohol. Zooplankton biomass was analyzed only for the samples collected with the $333 \mu \mathrm{m}$ mesh size net. Biomass was recorded as wet weight after eliminating the large and gelatinous organisms with a suction filtering system (Zavala-García \& Flores-Coto 1989). The samples were weighed on an analytical scale and the data were standardized to $\mathrm{g} 100 \mathrm{~m}^{-3}$.

The biomass and volume discharge values, previously transformed to $\operatorname{Ln}(x+1)$ and $1 / \sqrt{ } x$ respectively to normalize the variance, were analyzed considering the 5 areas into which the study area was divided, the 4 climatic seasons of the year, the distance from the coast and the depth of the stations. For each case, the obtained values represent the average biomass of an area, a season, or an area during a season.

The relationship of the average biomass values and the discharge for the whole study area was evaluated through a Pearson's correlation. In order to establish if there are significances differences of biomass between the 5 study areas and the climatic seasons, an analysis of variance was carry out (multifactorial ANOVA), as well as a StudentNewman-Keuls multiple comparisons test to determine which means were significantly different.

Spearman's rank correlation coefficient was applied to determine the distribution of the biomass in relation to the distance from the coast. The data were placed in $10 \mathrm{~km}-$ groups from the coast up to a distance of $100 \mathrm{~km}$. Those recorded beyond $100 \mathrm{~km}$ formed one single group (>100). Thus, each value represents the average of the biomass in each $10 \mathrm{~km}$-group within each area.

The Classification and Regression Trees (CART) technique proposed by Breiman et al. (1984) was applied to determine the relationship between the distribution of the zooplankton biomass (534 samples) on the continental shelf and adjacent oceanic region, and in the different areas, with respect to the climatic seasons of the year, the distance from the coast and the depth of the sampling stations.
The STATGRAPHICS Centurion XV, V. 15.2.06 and SPLUS, V. 8.0 software were used for all the statistics and classification tests.

\section{Results}

\section{CONTINental WATER Discharges}

The analysis of 10,697 data of 27 hydrometric stations recorded from 1944 to 1999 provided the volumes of the monthly and seasonal discharges of the 5 hydrological regions. The information points to a general pattern of continental water discharges throughout an annual cycle. The lower discharge values were recorded during the first 5 months of the year, the values increased to a maximum from June to September and October, and they decreased towards the last 2 months of the year. Seasonally, this means that the greater discharges occurred in summer and autumn and the lower ones in winter and spring (Fig. 2a).
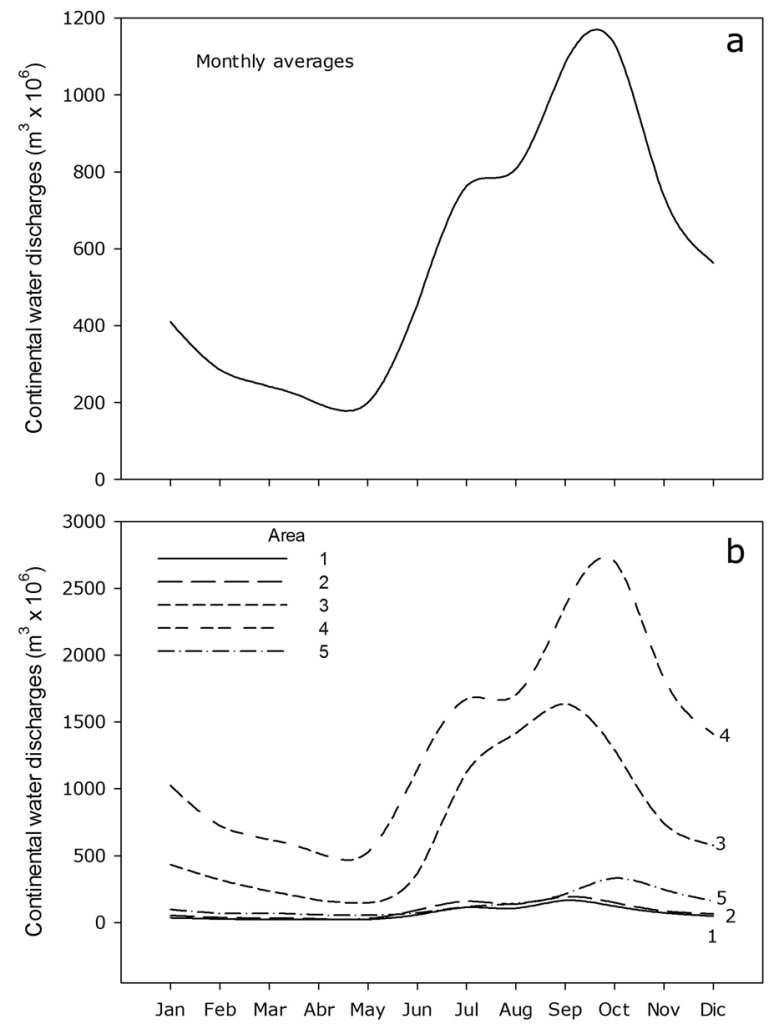

Figure 2.- Monthly averages of continental water discharges, for the whole study area and for each hydrological area (1-5) / Promedios mensuales de las descargas de aguas continentales, para toda la zona de estudio y para cada una de las áreas hidrológicas (1-5) 
The greater continental water discharges occurred in area 4 in Tabasco, the lower discharges were recorded in areas 1 and 2 in Veracruz and area 5 in Campeche, and area 3 recorded intermediate values (Fig. 2b). The maximum discharges throughout the hydrological cycle occurred in September in areas 1,2 and 3 and in October in areas 4 and 5.

\section{Abundance And Distribution of zooplankton BIOMASS}

The average biomass values expressed as $\mathrm{g} 100 \mathrm{~m}^{-3}$ varied among the different areas and seasons from 5.0 in area 1 in autumn to 31.4 in area 4 in summer. Areas 1,2 and 3 registered

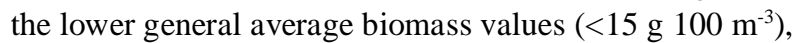

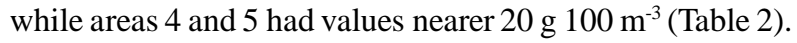

These data suggests a close relationship between biomass density and the volume of continental water discharges in the different areas. Thus, areas 1 and 2, where the lower values of zooplankton biomass were recorded, also recorded the lower values of continental water discharge, while greater values of these parameters were recorded for areas 3 and 4 . Area 5 however broke this relationship, with a high biomass but low discharges similar to those of areas 1 and 2 in Veracruz (Fig. 3).

Seasonally, the general pattern of biomass density was similar to that of the discharges, with low values during winter and spring that increased in summer and decreased in autumn. However, this relationship changed from one area to another (Fig. 4).

The Shapiro-Wilk test for normality was applied to the transformed values of average biomass and the water discharge volumes, the results showed a normal distribution with values of $\mathrm{W}=0.939, P=0.197$ and $\mathrm{W}=0.937, P=0.223$ respectively and the Pearson's correlation coefficient for biomass and discharges were $\mathrm{r}=0.689\left(\mathrm{~F}_{1,11}=16.297, \mathrm{~N}=20, P<0.05\right)$.

The multifactorial ANOVA results show a statistically significant relationship between biomass and the 5 study areas $\left(\mathrm{F}_{4,11}=5.24, P=0.0152\right)$, and the seasons $\left(\mathrm{F}_{3,11}=13.56, P=\right.$ 0.0002 ) (Table 3).

Considering the biomass values in the different areas, the Student-Newman-Keuls multiple comparisons test formed 2 homogeneous groups: the first with areas 1 and 2 that corresponded to 2 hydrological regions in Veracruz, and the second with areas 3, 4 and 5 that coincided with the areas of greater biomass production in Tabasco, Campeche and the region of Coatzacoalcos. A comparison of the biomass recorded for the different seasons of the year formed 2 homogeneous groups: the first with winter, spring and autumn, and the second with summer. It was during this season of the year that the greater biomass values were recorded in general in all the areas (Tables 4 and 5).
Table 2. Average biomass values $\left(\mathrm{g}_{\left.100 \mathrm{~m}^{-3}\right)}\right.$ per season and area in the states of Veracruz, Tabasco and Campeche / Valores promedio de biomasa ( $100 \mathrm{~m}^{-3}$ ), estaciones climáticas del año y áreas en los estados de Veracruz, Tabasco y Campeche

\begin{tabular}{|c|c|c|c|c|c|}
\hline \multirow{2}{*}{ Seasons } & \multicolumn{3}{|c|}{ Veracruz } & \multirow{2}{*}{$\frac{\text { Tabasco }}{4}$} & \multirow{2}{*}{$\begin{array}{c}\text { Campeche } \\
5\end{array}$} \\
\hline & 1 & 2 & 3 & & \\
\hline Winter & 8.7 & 6.0 & 14.0 & 19.2 & 15.4 \\
\hline Spring & 6.4 & 10.1 & 13.9 & 16.4 & 18.0 \\
\hline Summer & 18.4 & 9.3 & 18.1 & 31.4 & 23.3 \\
\hline Autumn & 5.0 & 6.5 & 13.3 & 15.9 & 20.0 \\
\hline Average & 11.8 & 8.0 & 15.0 & 20.0 & 19.8 \\
\hline
\end{tabular}

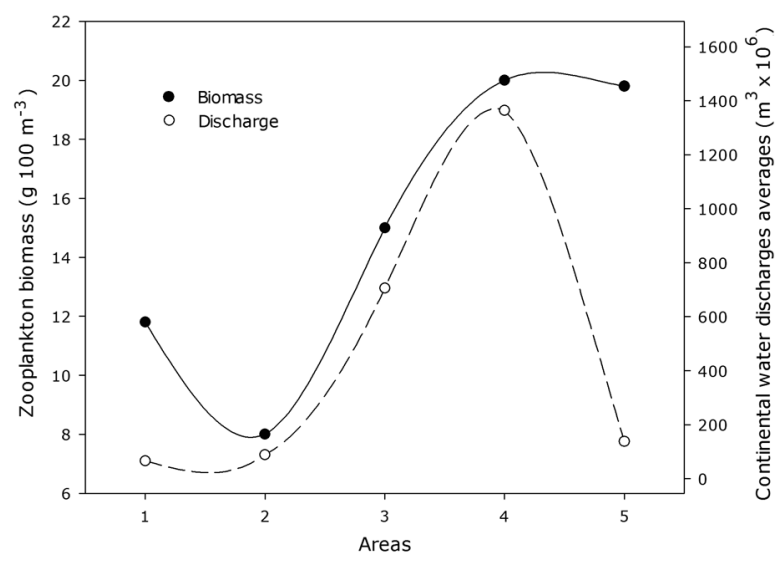

Figure 3. Zooplankton biomass and continental water discharge averages for each area / Promedios de la biomasa zooplanctónica y descargas de aguas continentales para cada una de las áreas

Table 3. Multifactorial variance analysis for biomass $\left(\mathrm{g} 100 \mathrm{~m}^{-3}\right)$ with respect to the seasons and $\mathbf{5}$ areas / Análisis de varianza

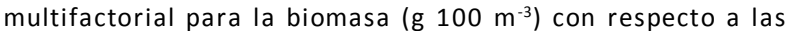
estaciones climáticas y las 5 áreas

\begin{tabular}{cccccc}
\hline Source & $\begin{array}{c}\text { Sum of } \\
\text { squares }\end{array}$ & $\begin{array}{c}\text { Degrees of } \\
\text { freedom }\end{array}$ & $\begin{array}{c}\text { Mean } \\
\text { square }\end{array}$ & $F$-test & $P$-value \\
\hline Main effects & & & & & \\
Areas (1-5) & 3.8442 & 4 & 0.9611 & 13.59 & 0.0002 \\
Seasons & 1.1129 & 3 & 0.3710 & 5.24 & 0.0152 \\
Residuals & 0.8488 & 11 & 0.0707 & & \\
Total (Corrected) & 5.8059 & 19 & & & \\
\hline
\end{tabular}



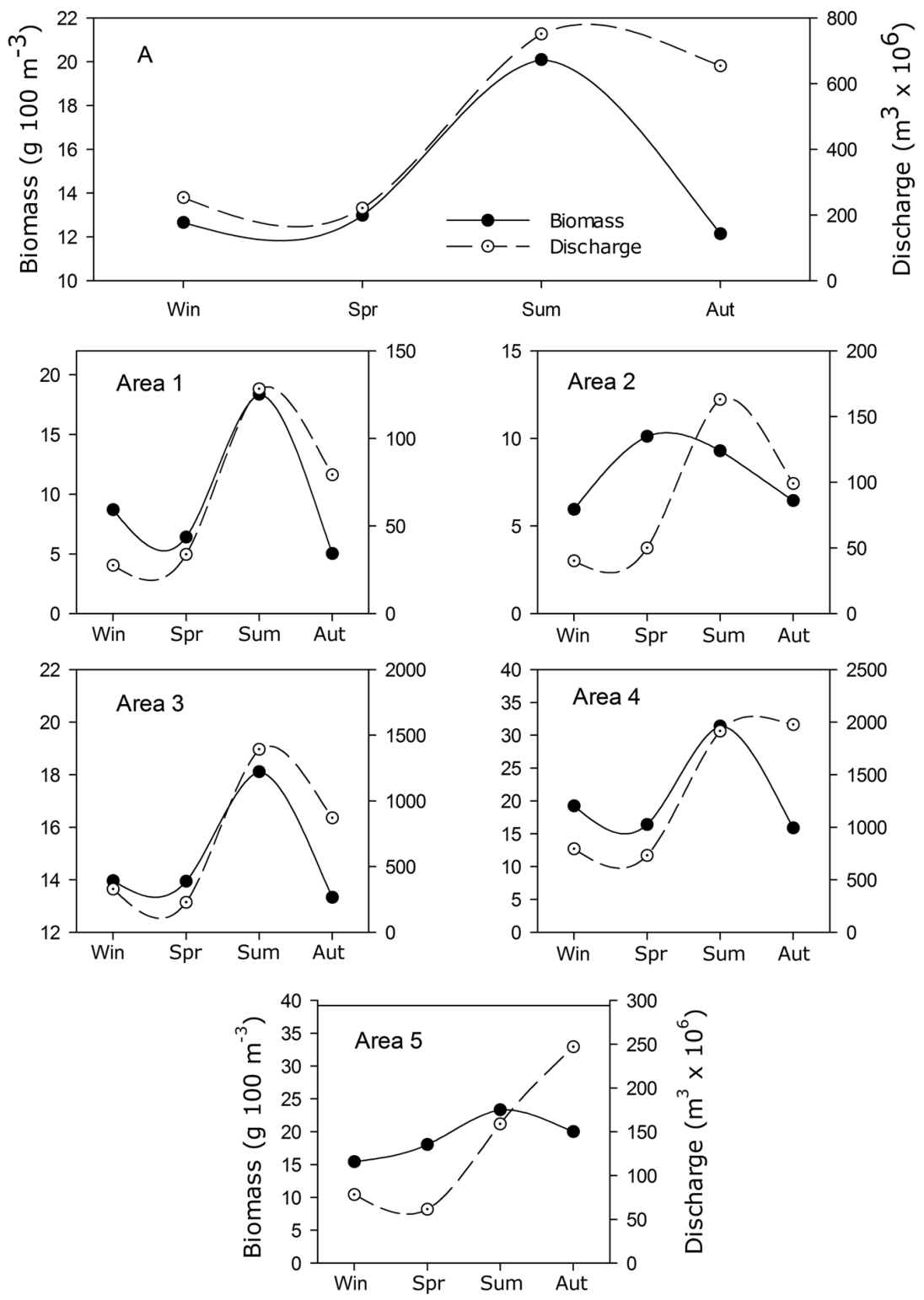

Figure 4. Seasonal averages of zooplankton biomass and continental water discharges for the whole study area (A) and for each area (1-5) / Promedios estacional de la biomasa zooplanctónica y descargas de aguas continentales, para toda la zona de estudio (A) y para cada una de las áreas (1-5) 
Table 4. Student-Newman-Keuls multiple comparisons values for

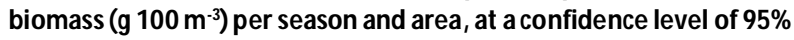
/ Comparaciones múltiples de Student-Newman-Keuls de los valores de biomasa ( $\left(\mathrm{g} 100 \mathrm{~m}^{-3}\right)$ por estaciones climáticas y áreas, a un nivel de confianza del $95 \%$

\begin{tabular}{lcccc}
\hline & N & Mean & $\begin{array}{c}\text { Standard } \\
\text { error }\end{array}$ & $\begin{array}{c}\text { Homogeneous } \\
\text { groups }\end{array}$ \\
\hline Areas & & & & \\
2 & 4 & 1.9058 & 0.13298 & 1 \\
1 & 4 & 1.9952 & 0.13298 & 1 \\
3 & 4 & 2.6185 & 0.13298 & 2 \\
5 & 4 & 2.8895 & 0.13298 & 2 \\
4 & 4 & 2.9382 & 0.13298 & 2 \\
Season & & & & \\
Winter & 5 & 2.4698 & 0.11893 & 1 \\
Spring & 5 & 2.3560 & 0.11893 & 1 \\
Summer & 5 & 2.4058 & 0.11893 & 1 \\
Autumn & 5 & 2.8662 & 0.11893 & 2 \\
\hline
\end{tabular}

The distribution of the biomass with respect to the distance from the coast produced a negative Spearman's correlation coefficient and a marked coast-ocean gradient off Veracruz and Tabasco. In contrast, in Campeche the pattern was inverted and the correlation was positive. The dependence of these parameters was statistically significant at a confidence level of 95\%, except for area 1 (Fig. 5).

The Tree analysis was applied to all the biomass samples (534). Its binary classification system showed that the distribution of the biomass was strongly conditioned by the depth of the stations. It formed 2 groups of stations, or branches, at the root of the tree. The first grouped the stations at depths $>101 \mathrm{~m}$ (213 stations) with very low biomass

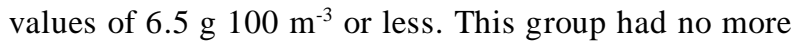
branches (Figs. 6a and b). The second grouped 321 stations with greater biomass values than those recorded for the first group. The next branching factor in this second group was the season, with one branch for summer and the other branch for winter, spring and autumn (Fig. 6a).

The branch for winter, spring and autumn generated 2 branches in which the areas were the main factor. The first branch grouped areas 1, 2 and 3 (106 stations) with an average

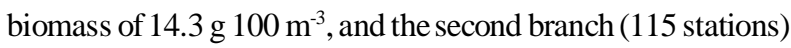

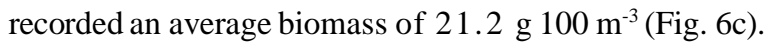

Table 5. Multiple comparisons values between each pair of means for areas and seasons / Valores de la comparación múltiple entre cada par de medias por áreas y épocas

\begin{tabular}{|c|c|c|c|}
\hline Areas & Significance & Seasons & Significance \\
\hline $1-2$ & 0.0895 & Win - Aut & 0.106 \\
\hline $1-3$ & * $\quad-0.6232$ & Win - Sum & -0.049 \\
\hline $1-4$ & * $\quad-0.9430$ & Win - Spr & $*-0.510$ \\
\hline $1-5$ & * $\quad-0.8942$ & Aut - Sum & -0.156 \\
\hline $2-3$ & * $\quad-07127$ & Aut - Spr & * -0.616 \\
\hline $2-4$ & * -1.0325 & Sum - Spr & * -0.460 \\
\hline $2-5$ & * $\quad-0.9837$ & & \\
\hline $3-4$ & -0.3197 & & \\
\hline $3-5$ & -0.2710 & & \\
\hline $4-5$ & 0.0487 & & \\
\hline
\end{tabular}

The branch for summer was divided by the depth into 2 new branches, one with the greater depths (> $33.5 \mathrm{~m}, 59$ stations)

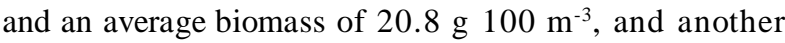
with the shallower depths $(<33.5 \mathrm{~m}, 41$ stations $)$ and an

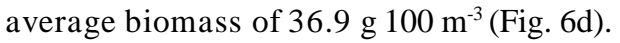

\section{Discussion}

The results obtained in this study indicate that the variation in zooplankton biomass throughout the year and throughout the study areas in the southern Gulf of Mexico is very similar to the pattern of continental water discharges.

The continental water discharges in the study area recorded lower values in winter and spring, a maximum in summer, and a decrease in autumn. The discharge volume of each hydrological region is determined by the surface area, as well as by the amount of rain that falls in each basin.

According to the Tree analysis for winter, spring and autumn, the main factor that determined differences in biomass distribution was the areas. Thus, areas 1, 2 and 3 off Veracruz presented the lower values, while areas 4 and 5 recorded the higher values. In the case of the summer, when the greater biomass values were recorded, it was the depth that conditioned the variations in the distribution. 


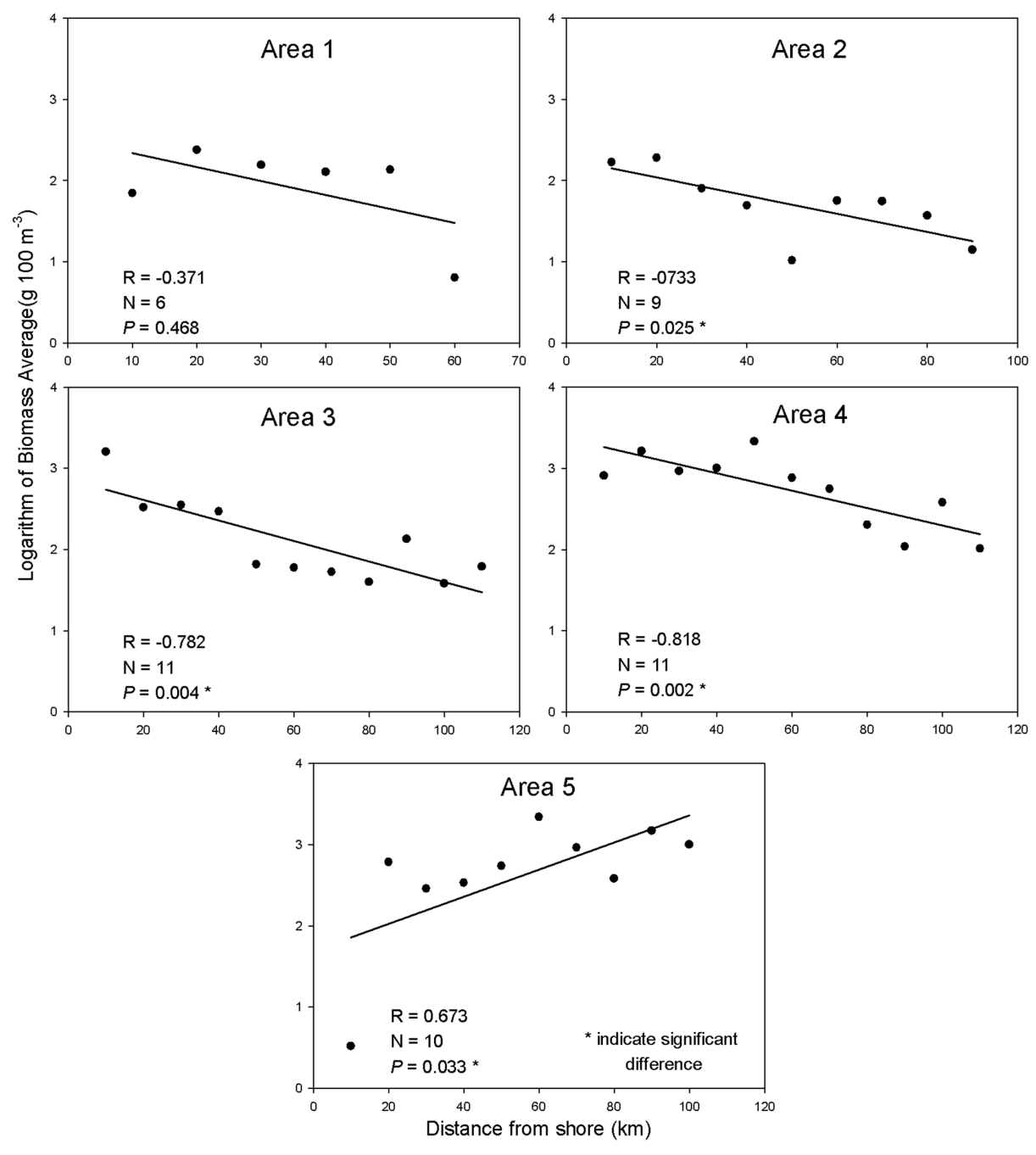

Figure 5. Zooplankton biomass distribution with respect to the distance from the coast in each area (1-5) / Distribución de la biomasa zooplanctónica respecto a la distancia a la costa, en cada una de las áreas (1-5)

Geographically, the greater biomass values were recorded in the southern of the Campeche Bay, off Tabasco and the lower values in the northwest of the bay, off Veracruz; areas were through the year the greater and lower continental water discharges occur, respectively. This indicates that magnitude of the biomass depend on the continental water discharges for their annual cycle, but also in direct relationship to the volume discharged into the ocean.
The Tree analysis made it possible to conclude that the biomass on the outer shelf (>101 m depth) and in the oceanic region of the southern Gulf of Mexico is always low, independently of the season of the year or of a particular area. A greater biomass was recorded on the shallow shelf, however its magnitude varied with respect to the area and the season. 

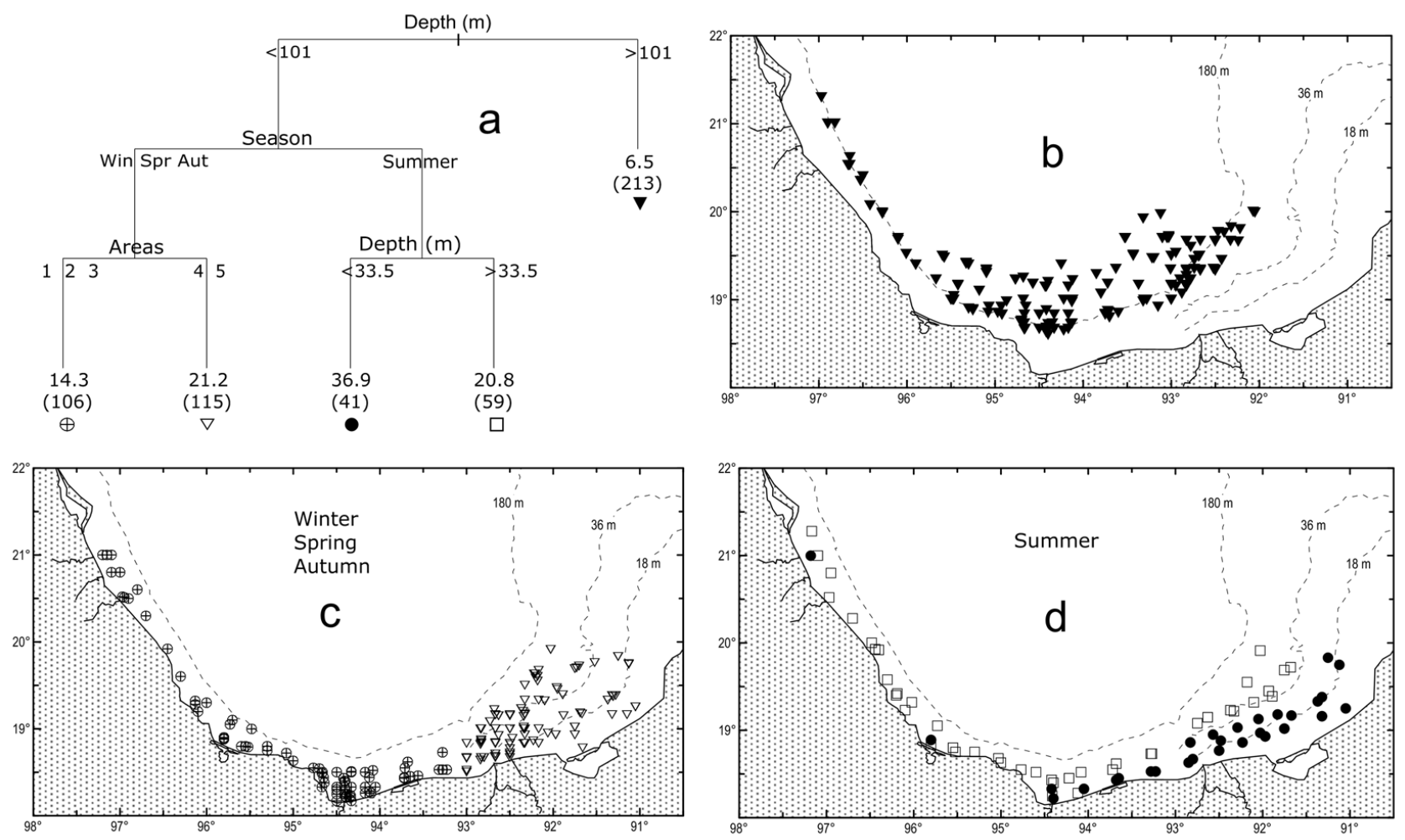

Figure 6. CART analyses applied to the biomass data recorded for the 5 areas. Classification and regression tree (a), stations located at $>101 \mathrm{~m}$ of depth (b), stations located at < $101 \mathbf{~ m}$ of depth in winter, spring and autumn (c) and in summer (d) / Análisis CART aplicado al total de datos de biomasa recolectadas en las 5 áreas. Árbol de clasificación y regresión (a), estaciones ubicadas a más de $101 \mathrm{~m}$ de profundidad (b), estaciones ubicadas a menos de $101 \mathrm{~m}$ de profundidad en invierno, primavera y otoño (c) y verano (d)

Variations in biomass, which depend on the volume of continental water discharges, respond to the greater concentration of nutrients that is discharged, together with river water, to the continental shelf(Lohrenz et al. 1990, Dagg \& Whitledge 1991, Chen et al. 2002), generating areas of high primary productivity that lead to a progressive increase in zooplankton biomass (Roman et al. 2005, Reaugh et al. 2007). High biomass densities have frequently been recorded y areas near the Grijalva-Usumacinta system (Flores-Coto et al. 1988, Monreal-Gómez et al. 2004, Loman-Ramos et al. 2007, Flores-Coto et al. 2010), for which reason this area is considered to be a highly productive region (CECODES 1981). The results of this study presented a very close relationship between these parameters, with a correlation coefficient of 0.689 and a statistical significance at a $95 \%$ confidence level.

The greater zooplankton biomass recorded near the coast, is an expected result of the production generated by the continental water discharges and their dispersion towards the sea, generated a coast-ocean gradient off Veracruz, and even more so off Tabasco due to the local currents (Zavala-Hidalgo et al. 2003). This dispersion process has been documented for this same area and other parts of the world for fish larvae, indicating that the penetration of freshwater onto the shelf takes place rapidly and carries with it whole associations of organisms as far as it spreads (Sabatés 1990, Reiss \& McConaugha 1999, Espinosa-Fuentes et al. 2004).

The biomass distribution pattern in area 5, which corresponds to the Campeche shelf, was opposite to that in the other 4 areas. In this area, greater biomass values were recorded at the stations located furthest from the coast. This suggests that the biomass in this region is advected from the Banco de Campeche and does not depend on the continental water discharges, but is generated on the Yucatán shelf after nutrient enrichment due to upwelling off Cabo Catoche (López-Veneroni et al. 1986, Merino-Ibarra 1992, Pérez de los Reyes et al. 1996, Merino 1997) or by coastal upwelling in the Banco de Campeche (Zavala-Hidalgo \& Fernández-Eguiarte 2006).

In conclusion the variation of the zooplankton biomass through the year in the southern Gulf of Mexico has a similar pattern to the continental water discharges, not only in terms of 
annual cycle, but in direct relation to the magnitude of the volume discharged into the ocean in each area, except in the Campeche-Yucatán shelf were the biomass has another origin.

\section{LITERATURE CITED}

Alatorre MA, F Ruiz \& D Salas de León. 1989. Efecto del paso de los frentes fríos atmosféricos sobre la Bahía de Campeche. En: González J, F Medina, M Romo \& M Martínez (eds). Memoria de la Reunión Anual 1987 de la Unión Geofísica Mexicana, pp. 186-193. Unión Geofísica Mexicana, Ensenada.

Biggs DC \& LL Sánchez. 1997. Nutrient enhanced primary productivity of the Texas-Louisiana continental shelf. Journal of Marine Systems 11:237-247.

Boltovskoy D. 1981. Atlas del zooplancton del Atlántico Sudoccidental y métodos de trabajo con el zooplancton marino, 936 pp. Publicación Especial del INIDEP, Mar de Plata.

Breiman L, JH Friedman, RA Olshen \& CI Stone. 1984. Classification and regression trees, 358 pp. Chapman \& Hall / CRC, London.

CECODES. 1981. Las lagunas costeras de Tabasco, un ecosistema en peligro, 109 pp. Centro de Ecodesarrollo, México.

Chen C, DA Wiesenburg \& L Xie. 1997. Influences of river discharge on biological production in the inner shelf: a coupled biological and physical model of the Louisiana-Texas shelf. Journal of Marine Research 55: 293-320.

Chen C, R Ji, DJ Schwab, D Beletsky, GL Fahnenstiel, M Jiang, TH Johengen, H Vanderploeg, B Eadie, JW Budd, MH Bundy, W Gardner, J Cotner \& PJ Lavrentyev. 2002. A model study of the coupled biological and physical dynamics in Lake Michigan. Ecological Modelling 152: 145168.

Clark D, K Aazem \& G Hays. 2001. Zooplankton abundance and community structure over a $4000 \mathrm{~km}$ transect in the northeast Atlantic. Journal of Plankton Research 23(4): 365-372.

Czitrom SPR, F Ruiz, MA Alatorre \& AR Padilla. 1986. Preliminary study of a front in Bay of Campeche, Mexico. In: Nihoul JCJ (ed). Marine interfaces ecohydrodynamics, pp. 301-311. Elsevier Oceanography Series, Amsterdam.

Dagg MJ \& TE Whitledge. 1991. Concentrations of copepod nauplii in the nutrient-rich plume of the Mississippi River. Continental Shelf Research 11: 1409-1423.

Espinosa-Fuentes ML \& C Flores-Coto. 2004. Cross-shelf and vertical structure of ichthyoplankton assemblages in the continental shelf waters of the southern Gulf of Mexico. Estuarine Coastal and Shelf Science 59: 333-352.

Espinosa-Fuentes ML, C Flores-Coto, L SanvicenteAñorve \& F Zavala-García. 2009. Vertical distribution of zooplankton biomass and ichthyoplankton density during an annual cycle on the continental shelf of the southern Gulf of Mexico. Revista de Biología Marina y Oceanografía 44(2): 477-488.
Fernández de Puelles ML, L Valdés, M Varela, MT Alvarez-Ossorio \& $\mathbf{N}$ Halliday. 1996. Diel variations in the vertical distribution of copepods off the north coast of Spain. ICES Journal of Marine Science 53: 97-106. <doi:10.1006/jmsc.1996.0009>

Flores-Coto C, L Sanvicente-Añorve, R Pineda-López \& MA Rodríguez-Van Lier. 1988. Composición, distribución y abundancia ictioplanctónica del sur del Golfo de México. Universidad y Ciencia 5(9): 65-84.

Flores-Coto C, F Zavala-García \& G Espinoza. 1993. Asociaciones ictioplanctónicas de la Bahía de Campeche, México (verano 1987). Facultad de Ciencias del Mar. Universidad Católica del Norte, Coquimbo, Serie Ocasional 2: 57-67.

Flores-Coto C, L Sanvicente-Añorve \& M SánchezRamírez. 2010. Appendicularian distribution and diversity in the southern Gulf of Mexico. Revista Mexicana de Biodiversidad 81: 123-131.

Gasca R, E Suárez-Morales \& L Vásquez-Yeomans. 1994. Estudio comparativo del zooplancton (biomasa y composición) en dos bahías del Mar Caribe mexicano. Revista de Biología Tropical 42(3): 595-604.

Gracia A, AR Vázquez-Bader, F Arreguín-Sánchez, L Shulltz-Ruiz \& JA Sánchez. 1997. Ecología de camarones peneidos. En: Flores-Hernández D, P Sánchez-Gil, JC Seijo \& F Arreguín-Sánchez (eds). Análisis y diagnóstico de los recursos pesqueros críticos del Golfo de México, Serie Científica 7: 127-144. Universidad Autónoma de Campeche, EPOMEX, Campeche.

Grimes CB \& JH Finucane. 1991. Spatial distribution and abundance of larval and juvenile fish, chlorophyll and macrozooplankton around the Mississippi River discharge plume, and the role of the plume in fish recruitment. Marine Ecology Progress Series 75: 109-119.

IMTA. 2000. Banco Nacional de Datos de Aguas Superficiales (BANDAS). 7 CDS. Secretaría del Medio Ambiente y Recursos Naturales, Comisión Nacional del Agua, Instituto Mexicano de Tecnología del Agua, Jiutepec, Morelos. [CDROM]

Kane J. 1993. Variability of zooplankton biomass and dominant species abundance on Georges Bank, 1977-1986. Fishery Bulletin 91:464-474.

Klemas V. 1980. Remote sensing of coastal fronts and their effects on oil dispersion. International Journal of Remote Sensing 1: 11-28.

Lohrenz SE, MJ Dagg \& TE Whitledge. 1990. Enhanced primary production at the plume/oceanic interface of the Mississippi River. Continental Shelf Research 10: 639-664.

Loman-Ramos L, U Ordóñez-López \& L Segura-Puertas. 2007. Variación espacial de la comunidad de medusas (Cnidaria) del sur del Golfo de México, durante el otoño de 1999 Hidrobiológica 17(3): 203-212. 
López-Veneroni D, F Ramos-Durán \& G Aguilera-Lozano. 1986. Condiciones hidrológicas en el norte de la Península de Yucatán en julio de 1984. Investigaciones Oceanográficas 3(3): 120-155.

Merino M. 1997. Upwelling on the Yucatan shelf: hydrographic evidence. Journal of Marine Systems 13: 101-121.

Merino-Ibarra M. 1992. Afloramiento en la Plataforma de Yucatán: Estructura y fertilización. Tesis de Doctorado, Unidad Académica de los Ciclos Profesional y de Posgrado del Colegio de Ciencias y Humanidades, ICMyL, Universidad Nacional Autónoma de México. México, 255 pp.

Monreal-Gómez MA, DA Salas de León, AR Padilla-Pilotze \& MAAlatorre-Mendieta. 1992. Hydrography and estimation of density currents in the southern part of the Bay of Campeche, Mexico. Ciencias Marinas 18(4): 115-133.

Monreal-Gómez MA, DA Salas de León \& A Gracia-Gasca. 2004. Golfo de México, circulación y productividad. Ciencias 76:24-33.

Nowlin WD Jr. 1972. Winter circulation patterns and property distributions. In: Capurro LRA \& JL Reid (eds). Contributions on the physical oceanography of the Gulf of Mexico, pp. 3-15. Gulf Publishing Company, Houston.

Pérez de los Reyes R, VI Del Río, PM Signoret, GA Gallegos, RI Penié, VC Gil, C Bulit, N Melo-González, F MüllerKarger, S Cerdeira-Estrada \& M Merino-Ibarra. 1996. Reporte de un frente hidrológico al noreste de la Península de Yucatán. Manifestaciones químicas e hidrobiológicas. Boletín de la Sociedad Meteorológica de Cuba 2: 1-16.

Reaugh ML, MR Roman \& DK Stoecker. 2007. Changes in plankton community structure and function in response to variable freshwater flow in two tributaries of the Chesapeake Bay. Estuaries and Coasts 30: 403-417.

Reiss CS \& JR McConaugha. 1999. Cross-frontal transport and distribution of ichthyoplankton in Virginia shelf waters associated with Chesapeake Bay plume dynamics. Coastal Shelf Science 19: 151-170.

Roman M, X Zhang, C McGilliard \& W Boicourt. 2005. Seasonal and annual variability in the spatial patterns of plankton biomass in Chesapeake Bay. Limnology and Oceanography 50(2): 480-492.
Sabatés A. 1990. Changes in the heterogeneity of mesoscale distribution patterns of larval fish associated with a shallow coastal haline front. Estuarine Coastal Shelf Science 30: 131140 .

Salas de León D, A Monreal-Gómez, L Sanvicente-Añorve \& C Flores-Coto. 1998. Influence de la circulation à long terme sur la distribution des organismes zooplanctoniques dans la Baie de Campeche, Mexique. Oceanologica Acta 21(1): $87-$ 93.

Shirazago GB. 1991. Hidrografía y análisis frontogénico en el sur de la Bahía de Campeche. Tesis Maestría, Unidad Académica de los Ciclos Profesionales y de Posgrado, Colegio de Ciencias y Humanidades, ICMyL, Universidad Nacional Autónoma de México, México, 141 pp.

Steinberg DK, JS Cope, SE Wilson \& T Kobari. 2008. A comparison of mesopelagic mesozooplankton community in the subtropical and subarctic North Pacific Ocean. Deep Sea Research 55: 1615-1635.

Tapanes JJ \& F González-Coya. 1980. Hidrometeorología del Golfo de México y Banco de Campeche. Geofísica Internacional 19(4): 335-354.

Vera-Mendoza RR \& DA Salas de León. 2014. Effect of environmental factors on zooplankton abundance and distribution in river discharge influence areas in the southern Gulf of Mexico. In: Amezcua F \& B Bellgraph (eds). Fisheries management of Mexican and Central American estuaries, Estuaries of the World: 93-112 Springer, Dordrecht.

Zavala-García F \& C Flores-Coto. 1989. Medición de biomasa zooplanctónica. Anales del Instituto de Ciencias del Mar y Limnología, UNAM 16:273-278.

Zavala-Hidalgo J, SL Morey \& JJ O'Brien. 2003. Seasonal circulation on the western shelf of the Gulf of Mexico using a high-resolution numerical model. Journal of Geophysical Research 108(C12), 3389.< http://dx.doi.org/10.1029/ 2003JC001879>

Zavala-Hidalgo J \& A Fernández-Eguiarte. 2006. Propuesta para la regionalización de los mares mexicanos desde el punto de vista de los procesos físicos: el Golfo de México. En: Córdova A, F Rosete-Vergés, G Enríquez-Hernández \& B Hernández de la Torre (eds). Ordenamiento ecológico marino. Visión temática de la regionalización, pp. 21-31. Instituto Nacional de Ecología-SEMARNAT, México. 